中学校のロッカーの使われ方の分析

$$
\begin{aligned}
& \text { 正会員船越 徹* 同 OZEサウール** }
\end{aligned}
$$

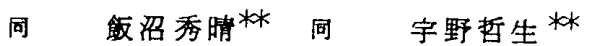

\title{
I. 研究目的・概要本研究は計画学の成果を取り
} 入れて設計された $\mathrm{V}$ 型(兵庫県八鹿町立青溪中： $\mathrm{S}$.


黑区立 1 中 $^{* 8}: M 、 1965$ 年10月21.22 日、晴) U.V 型 (東京都江東区立 3 中 $^{* 4}: K 、 1965$ 年 9 月 28.29 日、 晴）中学校の休み時間（昼休み、朝、放課後をのぞい ていずれる10分休み)飞おけるロッカ一の使われ方を 調査したものである。

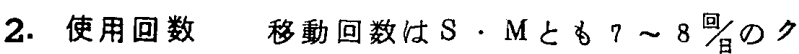
ラスが多くKの約 2倍になっている。てれは㤬とんど 毎休み時間に移動を行らてとを示しており、てれに伴 らロッカ一使用回数を見るとSの方がM上りる全般的 に多らととがわかる。Mで屋食時、登校時、大移動 時飞多く、特別教室群、普通数室群内の移動時飞少々 とレラバラッキが見られるが、Sの場合には移動のタ イブによる使用傾向の差壮頙著ではない。平均すると Sては 7.0 回/月、Mでは $3.0 \sim 4.0$ 回/・日使用がなされて 衫。ての使用頻度の差は学校规模加主な原因である と思われ、6クラスのSでは10分休み任全校生徒の8 6

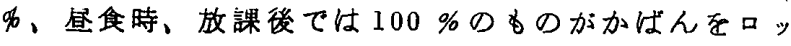

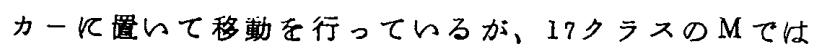
昼食時の63\%の他はこの種の移動恃绖とんど見られな い。徉ってSてはロッカーが移動の中継点という上り はむしろそてから全ての移動加始る出発点と左ってい るのである。一般化昼食時の使用が多的が、てれは主 飞持物が給食菹備及び㡺休みの遊びの邪磨に存るから だと思かれる。Sでは1時間おを使用がわずかなが ら增えておりてれは 2 時間分の教材を持占步く移動か

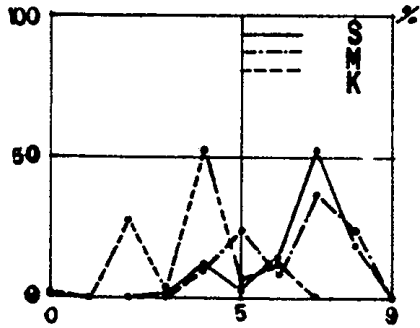

图-11日の移䄭回数

*1生徒の持物の処理につんて

*2 建物設計资枚成第 4 卷

*3 同上

*4 同上



あるととを示摔している。

3. 使用時間 SD10分休みの使用は授業終了後 3 〜4分頃にビークがあり50〜70人が同時保居合わせて $2.1 \sim 2.9$ 少でかなり潍雑するが以磱減少して7〜9分頃 に第2のビークがある。Mでは任とんどの使用が2〜 5 分の間になされている。 $\mathrm{S} の$ 第1のピークは前の時 間の教材収納するために生し、第2のビークは次の 時間の準備のためと思われ、この間にロッカ一をわり の遊びが入っている。Mでは収納一一準備が末分化の 結果 1 つのビークだけを形成する。従ってSの移動時 間は規模に比して長くなり、ロッカーから次の数室へ の移動はどークがなくてバラッキの大をい移動となっ ている。その結果移動の重り合んが生じてす次の教室 前てたまる生徒は高々10人位で任とんど授業の妨害に はならなかった。ロッカ一まわりでは読書などる行わ れ使用時間が 3〜5分に及ぶすが特に女子に多かった。 Mでは移動位一目的的でルートは值行するるのか多 らが、Sでは多目的的でートは放射状になっている しとが多い。たとえばMではハルコニーを移䡃に使 5

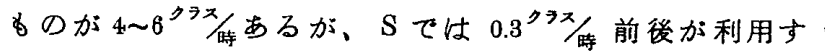
るにすをず大部分がロッカーを核とする集合、発散を くり返している。

4.むすび 以上の考察から移動回数が增える上口 ッカースベースを生徒の生活の挂点とするよらな使わ れ方がなれるととがわかった。とれから体育館、食 堂、戸外等と関連つけて贱点としての性格を一層強め ることにより移動で若干問題があると思われる $\mathrm{V}$ 型 $\mathrm{PV}$ 型の新しん施設計画がなされ得ると思われる。

$\begin{array}{llllllll}0 & 1 & 2 & 3 & 4 & 5 & 8 & 7\end{array}$


|厚体|

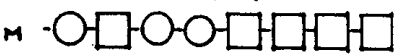

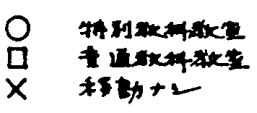

図-3 移動の喠類

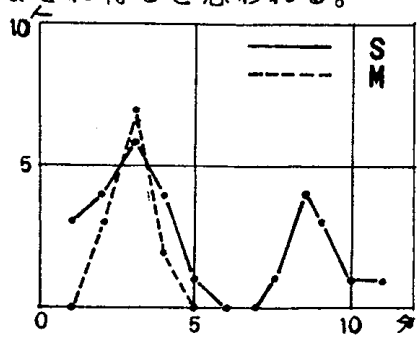

図一 4 使用時刻 (1クラス)
P 36 炤

P $37 \%$

P 36 ,

标東京大学大学院生 